O. V. PYLYPENKO, O. D. NIKOLAYEV, I. D. BASHLIY, S. I. DOLHOPOLOV

\title{
MATHEMATICAL SIMULATION OF DYNAMIC PROCESSES IN THE PROPELLANT FEED SYSTEM OF LAUNCH VEHICLE SPACE STAGES IN MICROGRAVITY
}

\author{
Institute of Technical Mechanics \\ of the National Academy of Sciences of Ukraine and the State Space Agency of Ukraine \\ 15 Leshko-Popel St., 49005, Dnipro,Ukraine; e-mail:dolmrut@gmail.com
}

The steady trend towards the development of space stages capable of putting into orbit several spacecraft with a single launch vehicle (LV) by multiple restarts of the stage sustainer engine in microgravity calls for the solution of a complex of problems aimed at assuring the continuity of the liquid propellant components in the propulsion system feed lines. The aim of this paper is mathematical simulation of dynamic processes in the propellant feed system of LV space stages to assess its operability in microgravity in passive flight segments with an operating attitude control and stabilization system and at sustainer engine starts in periods with minimum tank filling levels. To solve these problems, the authors developed a methodology based on the finite-element method, the volume of fluid method, 3D CAE technologies, and the impedance method.

The paper presents mathematical models of dynamic processes in a liquid-propellant LV space stage propulsion feed system that has a capillary propellant management system. The mathematical models of spatial oscillations of a LV space stage with a spacecraft developed with account for the design features of the in-tank devices and propellant feed systems made it possible to determine the mode shapes and the motion parameters of the free surfaces of the propellant components in the tanks (the oxidizer tank and the fuel tank) of the stage and identify flight regimes potentially dangerous in terms of the possibility of the pressurization gas or the substituent gas dissolved in the propellant components penetrating into the engine propellant lines. Quantitative estimates of the propellant management device operability in these regimes were obtained.

The mathematical models of hydrodynamic processes in a space stage liquid propellant propulsion system presented in this paper allow one to identify sustainer engine start conditions in which the pressurization gas may penetrate in the engine propellant lines and determine the parameters of dynamic processes in a space stage feed system at sustainer engine starts and cutoffs. The mathematical model of low-frequency hydrodynamic processes in a space stage feed system at sustainer engine starts and cutoffs was tested using the results of experimental studies (on water) of space stage sustainer engine cutoffs, and the calculated oscillation frequencies and amplitudes were shown to be in satisfactory agreement with the experimental ones.

Keywords liquid-propellant launch vehicle, space stage, propellant management device, hydrodynamic processes in tanks, finite-element method, volume of fluid method, free surface of propellant components in tanks, mathematical simulation.

1. Serdyuk V. Launch Vehicle Design (in Russian). Moscow : Mashinostroyeniye, 2009. 504 pp.

2. Pylypenko O. V., Zavoloka A. N., Nikolayev O. D., Sviridenko N. F. et al. Workability of in-tank propellant management devices in the feed system of a launch vehicle space stage propulsion system (in Russian). Aerogasdynamics: Problems and Prospects (collected articles). 2006. Issue 2. Pp. 88-100.

3. Galiev Sh. U., Borisevich V. K.,Potanenko A. N., Plisko-Vinogradsky A. F. Technique for calculating the loas exerted by a liquid plume on a tank cover (in Russian). Problemy Prochnosti. 1984. No. 5. Pp. 47-52.

4. Nikolaev A. D., Bashliy I. D. Determination of parameters of propellant oscillation in tanks of space stages of launch vehicles before restarting the cruise engine with low filling (in Russian).Teh. Meh. 2013. No. 3. Pp. 1020

5. Mikishev G. N., Rabinovich B. I. Dynamics of Thin-Walled Structures with Compartments Containing a Liquid (in Russian).Moscow: Mashinostroyeniye, 1971. 564 pp.

6. Pylypenko O. V., Degtyarev A. V., Zavoloka A. N., Kashanov A. E., Nikolaev A. D., Sviridenko N. F., Bashliy I. $D$. Determination of parameters of gas and fluid structures forming in propellant components in starting the cruise engine of space stage with low filling its tanks (in Russian). Teh. Meh. 2014. No. 4. Pp. 3-13.

7. Dolgopolov S. I., Zavoloka A. N., Nikoilaev A. D., Sviridenko N. F., Smolensky D. E. Parametric determination of hydrodynamic processes in feed system of space stage in stopping and starting the cruise engine (in Russian). Teh. Meh. 2015. No. 2. Pp. 79-92.

8. Shevyakov A. A., Kalnin V. M., Naumenkova N. V., Dyatlov V. G. Theory of Automatic Rocket Engine Control (in Russian). Moscow : Mashinostroyeniye, 1978. 288 pp.

9. Belyaev E. N., Chervakov V. V. Mathematical Simulation of Liquid-Propellant Rocket Engines (in Russian). Moscow: MAI-PRINT, 2009. 280 pp.

10. Lebedinsky E. V., Kalmykov G. P., Mosolov S. ., Koroteev A. S. Working Processes in a Liquid-Propellant Rocket Engine and Simulation Thereof (in Russian). Moscow: Mashnostroyeniye, 2008. 511 pp. 
11. Di Matteo, Fr., De Rosa, M., Onofri, M. Start-Up Transient Simulation of a Liquid Rocket Engine. AIAA 2011-6032 47 $7^{\text {th }}$ AIAA/ASME/SAE/ASEE Joint Propulsion Conference \& Exhibit (31 July - 03 August 2011), San Diego, California (15 pp.). Retrieved from www.enu.kz/repository/2011/AIAA-2011-6032.pdf

12. Kohnke P. Ansys, Inc. Theory Manual 001369, Twelfth Edition. Canonsburg: SAS IP, Inc., 2001. 1266 pp/

13. Kozlov A. A., Novikov V. N., Solov'ev E. V. Rocket Liquid-Propellant Propulsion Feed and Control Systems (in Russian). Moscow: Mashinostroyeniye, 1988. 352 pp.

14. Hirt C. W., Nichols B. D. Volume of fluid (VOF) method for the dynamics of free boundaries. Journal of Computational Physics. 1981. No. 39 (1). Pp. 201-225.

15. Mikishev G. N., Churilov G. A. Effect of surface tension and wetting angle on liquid oscillations in vessels (in Russian). Spacecraft Dynamics and Space Exploration. Moscow: Mashinostroyeniye, 1986. Pp. 164-175.

16. Blokha I. D., Zavoloka A. N., Nikolayev O. D., Sviridenko N. F. Effect of pogo vibrations of a launch vehicle upper stage on the operability of the in-tank propellant management devices in the sustainer engine feed system (in Russian). Teh. Meh. 2005. No. 2. Pp. 65-74.

17. Davydov $S$. A. Calculation of the coefficient of penetration of a submerged liquid jet through a thin metal mesh (in Russian). System Design and Characteristic Analysis of Aerospace Hardware (collected articles). Dnipropetrovsk, 2004. Issue V. Pp. 13-21.

18. Sichevoy A. V., Davydov S. A., Gorelova $K$. V. Dynamic loading factor of mesh-type propellant management devices (in Russian). System Design and Characteristic Analysis of Aerospace Hardware (collected articles). Dnipropetrovsk, 2010. Issue . Pp.. 106-113.

19. Dolgopolov S. I. Mathematical simulation of the dynamics of a liquid in long pipelines using hydrodynamic elements (in Russian). Teh. Meh. 2006. No. 2. Pp. 114-120.

23. Charny I. A. Unsteady Flow of a Real Liquid in Pipes (in Russian). Moscow: Nedra, 1975. 296 pp.

22. Pilipenko V. V., Zadontsev V. A., Natanzon M. S.. Cavitation Oscillations and Hydrosystem Dynamics (in Russian). Moscow : Mashinostroyeniye, 1977. 352 pp.

Received on November 13, 2018 , in final form on December 12, 2018 